\title{
An Evaluation of the Financial Performance of REITs in Borsa Istanbul: A Case Study Using the Entropy-Based TOPSIS Method
}

\author{
Mehmet İslamoğlu ${ }^{1}$, Mehmet Apan ${ }^{1} \&$ Ahmet Öztel ${ }^{2}$ \\ ${ }^{1}$ Faculty of Business, Karabuk University, Karabuk, Turkey \\ ${ }^{2}$ Faculty of Economics and Administrative Sciences, Bartın University, Bartın, Turkey \\ Correspondence: Mehmet İslamoğlu, Faculty of Business, Karabuk University, Pbx.78050, Karabuk, Turkey. Tel: \\ 90-544-246-3920. E-mail: mislamoglu75@gmail.com
}

Received: March 19, 2015

Accepted: April 2, 2015

Online Published: April 11, 2015

doi:10.5430/ijfr.v6n2p124

URL: http://dx.doi.org/10.5430/ijfr.v6n2p124

\begin{abstract}
Real Estate Investment Trusts are financial intermediaries which facilitate the provision of finance for real estate properties and thus play a key role in the development of the real estate market. An accredited assessment of financial performance is more vital today as there is increasing competition which poses a risk to maintaining the market share of companies. Therefore, the valuation of companies in terms of liquidity, profitability, turnover and capital structure help managers to take the necessary measures and thus contribute to the soundness of the companies. In this study, a financial analysis of REITs between 2011Q1-2014Q3 within the financial market in Turkey was measured using Entropy based TOPSIS (Technique for Order Preference by Similarity to An Ideal Solution) which is a widely-used Multi-Criteria Decision Making (MCDM) method. According to the empirical results, for all the periods, Avrasya, Akmerkez, Sinpaş, Kiler and İş were found to be the most efficient REITs respectively, whereas, İdealist, Atakule, Alarko, Nurol and Vakif demonstrated the worst financial performances throughout the whole period.
\end{abstract}

Keywords: REIT, MCDM, TOPSIS, entropy, financial performance

\section{Introduction}

Real Estate Investment trusts are closed-end investment companies managing portfolios composed of real estates, real estate-based projects and capital market instruments based on real estate (http://www.cmb.gov.tr/indexpage.aspx?pageid=5). To qualify as a REIT, a real estate company must satisfy certain requirements set forth by Government legislation, including the distribution each year to its shareholders of at least $90 \%$ of its taxable income. In return for distributing most or all of its taxable income, the company pays no corporate tax on the distributed income. Non-REIT property companies are those which are either domiciled in countries without REIT legislation or which have chosen not to opt for REIT status.

Real estate investment trusts provide finance for real estate properties, such as apartments, hotels, resorts, self-storage facilities, warehouses, business centers and shopping malls or large-scale real estate projects. Companies must bear substantial financial burden to perform such large projects. This often means that they must finance their equity through loans, resulting in the expense of paying interest. However, such projects can be financed with funds collected from individual and institutional investors in exchange for shares in real estate investment trusts, thereby substantially alleviating the company's financial burden.

REITs provide a way for individual investors to earn a share of the income produced through commercial real estate ownership, without actually having to go out and buy commercial real estate (http://www.sec.gov/answers/reits.htm).

The aim of this study was to identify whether publicly traded REITs on Borsa Istanbul (Istanbul Stock Exchange) are productive and efficient in terms of various criteria. Therefore, firstly the ratios used in measuring productivity and efficiency will be defined and will then be processed using TOPSIS, which is a non-parametric, mathematical based multi-criteria decision-making method. According to the results of productivity and efficiency calculations related to the activities of the REITs, the leading REITs will be identified.As of 31.12.2014, 31 REITs were quoted on Borsa Istanbul and the study covers the period of 2011Q1 to 2014Q3.

The paper proceeds as follows: Section 2 provides a brief summary of the backround of the domestic and foreign REITs Market. In Section 3, literature about productivity and efficiency measurements of firms using various 
methods is briefly introduced. The data and methodology of the study are described in Section 4. The empirical results are presented in Section 5and finally the conclusion is made in Section 6.

\section{Background of the Domestic and Foreign REIT Industry}

Since the Industrial Revolution, despite developments in capital markets and the emergence of new investment vehicles, real estate investments have been preferred by investors compared to other investment vehicles, due to low risk and long-term returns.

The global REIT industry has been a major participant in transaction markets in the last threeyears. Real Capital Analytics (RCA) estimates that REITs accounted for 14\% of transactions by volume in 2012 and that percentage rose to $20 \%$ in the first half of 2013 (Global Perspectives: 2013 REITs Report).

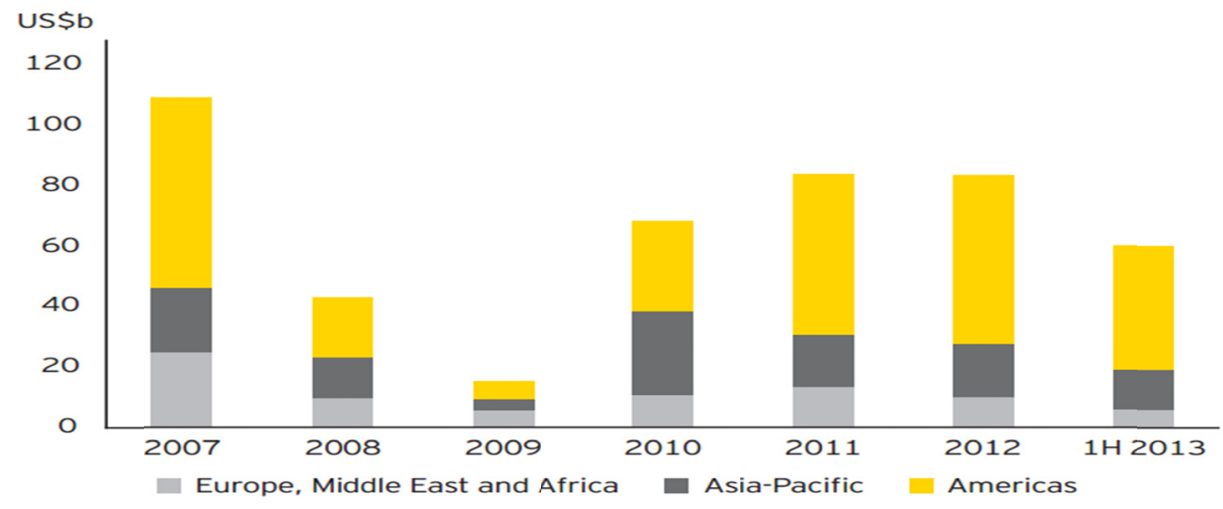

Figure 1. Global REITs investment volumes

In the USA, first in 1960, Congress authorized REITs to encourage individuals to invest in long-term but liquid real estate properties. However, by 1993, the number of real estate properties had significantly decreased due to the Savings and Loan Crisis which developed in the late 1980s. The Tax Reform Act that came into force in 1986 and overbuilding in real estate industry stimulated real estate investment on an individual and institutional basis. As a result, REITs grew from an estimated market value of equity of $\$ 9$ billion in 1990 to $\$ 89$ billion in 1996 and to $\$ 140$ billion at the end of 1997 (Vincent, 1999). As of June 30, 2014, all US REIT equity market capitalization was valued at $\$ 816$ billion and REITs own approximately $\$ 1.7$ trillion of commercial real estate assets, including stock exchange-listed and public, non-listed REITs (http://www.reit.com/investing/industry-data-research/industry-data).

Table 1. Real estate investments trusts - 2013 total return proxy data

\begin{tabular}{|llllll|}
\hline Period & 1-year & 3-year & 5-year & 10-year & 20-year \\
\hline Annual Compound Returns \% & 3.2 & 9.98 & 16.68 & 7.77 & 9.84 \\
\hline Cumulative Returns \% & 3.2 & 33.02 & 116.29 & 111.3 & 553.97 \\
\hline
\end{tabular}

Note: January 1994 - December 2013; Benchmarked at December $1993=100.00$ )

Source: USA REITs 2013 Total Proxy

Data(http://www.reit.com/investing/industry-data-research/annual-proxy-data)

In Table 1 above, short and long-term average annual compound and cumulative returns in USA REITs Market are displayed. As can be seen from the table, especially over a 20-year period, REITs offer attractive returns.

In Europe, the Netherlands was the first country to introduce regulations concerning REITs in 1969. In other European countries there were no regulations implemented until the 1990s. It has been observed that before REITs, private real estate companies and other institutional real estate investors such as real estate investment funds were active in the real estate market.

The Europe Developed Real Estate sub-sector allocations include retail REITs 35.8\%, real estate holdings \& $\begin{array}{llllll}\text { development } 28.8 \% & \text { and } & \text { industrial } & \text { office } & \text { REITs } & 24.6 \%\end{array}$ (http://www.etftrends.com/2014/10/europe-reits-etf-for-a-recovering-property-market/). 
In Table 2 below, the Developed Europe Real Estate country weightings include U.K. at 39\%, Netherlands $18 \%$, Germany 12\%, France 9\%, Sweden 6\%, Switzerland 5\%, Belgium 3\%, Austria 2\%, Spain 2\%, Italy 2\% and Finland $1 \%$. The European Real Estate Market remains relatively small with the market capitalization of REITs at $€ 144$ billion as of September 30, 2014, compared to €282.8 billion in Asia and €497.3 billion in North America.

Table 2. Country breakdown of REITs in Europe

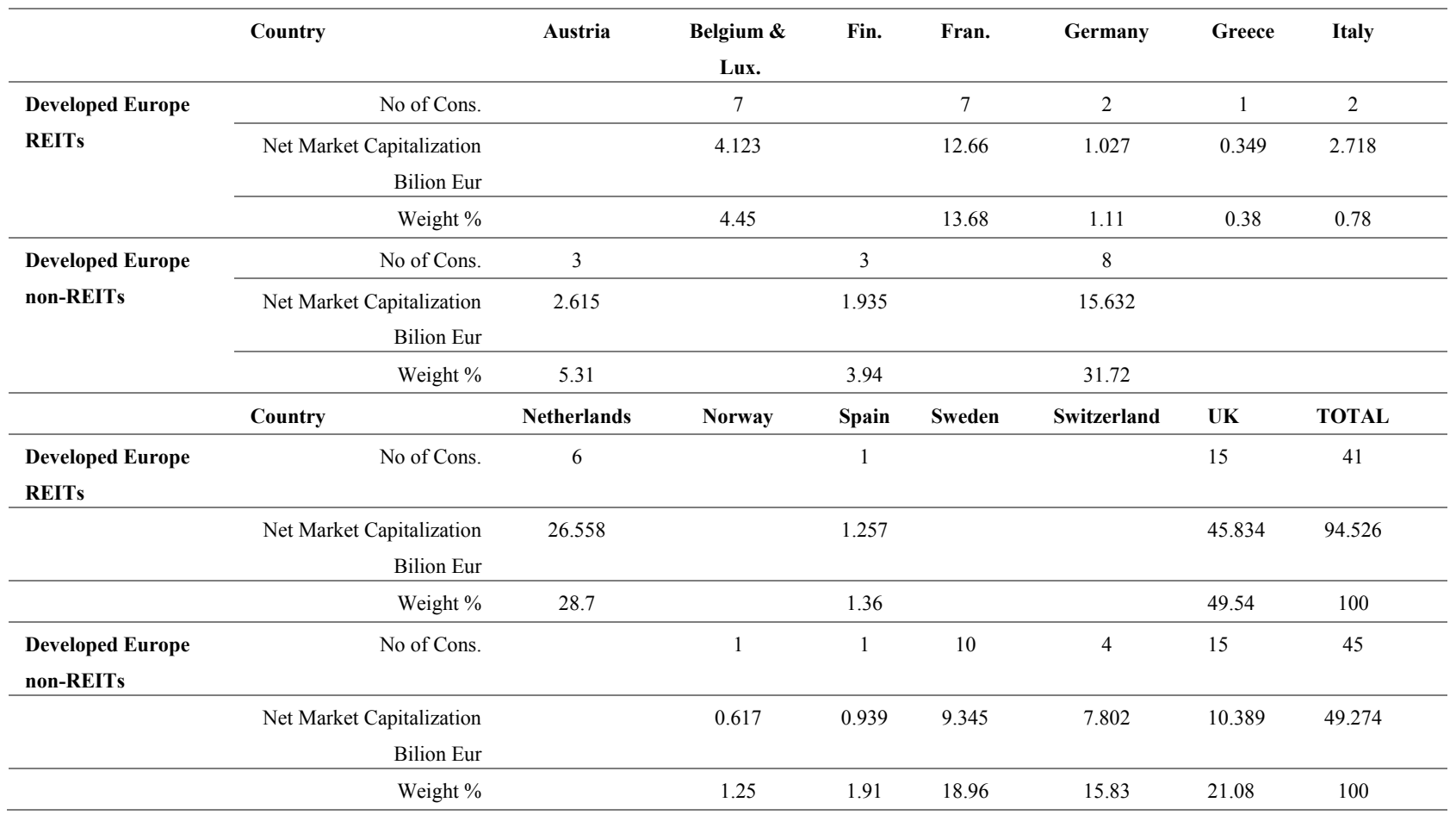

Source: FTSE EPRA/NAREIT, Developed Europe REITs and Non-REITs Indices, 30.09.2014

As one of the most important institutional investors in developed economies, REITs play a key role in the real estate market. With lower risks and offering higher returns compared to other investment vehicles in the long-term, real estate investments in emerging economies such as Turkey are in high demand by investors.

The Turkish Capital Market became familiar with REITs in the early 1990s. The first legislation on REITs was introduced in 1995, 2 REITs were founded in 1996 with shares quoted on Borsa Istanbul with a market capitalization of 43 million \$ within the first quarter of 1997. With the foundation of 6 more REITs, by the end of 1998 the market value of the 8 REITs in the Real Estate Market reached 792 million\$. After the 2008 financial crisis which primarily affected the real estate industry, the market value of real estate properties decreased drastically. However, with the regeneration of stock markets worlwide in 2009, 2010 was a boom year on Borsa Istanbul. Not only the recovery in stock prices of the REITs on Borsa Istanbul, but also with a notable increase in real estate projects (shopping malls and mortgages) and correspondingly new REITs on Borsa Istanbul, the market capitalization of REITs reached 11 billion\$ which was the all-time highest level.

Table 3. Market capitalization of REITs trading on Borsa Istanbul (Million \$)

\begin{tabular}{lccccccccc}
\hline Year & $\mathbf{1 9 9 7}$ & $\mathbf{1 9 9 8}$ & $\mathbf{1 9 9 9}$ & $\mathbf{2 0 0 0}$ & $\mathbf{2 0 0 1}$ & $\mathbf{2 0 0 2}$ & $\mathbf{2 0 0 3}$ & $\mathbf{2 0 0 4}$ & $\mathbf{2 0 0 5}$ \\
\hline No of Cons. & 2 & 5 & 8 & 8 & 8 & 9 & 9 & 9 & 10 \\
\hline Market value & 43 & 434 & 796 & 792 & 621 & 661 & 845 & 1,03 & 1,645 \\
\hline Year & $\mathbf{2 0 0 6}$ & $\mathbf{2 0 0 7}$ & $\mathbf{2 0 0 8}$ & $\mathbf{2 0 0 9}$ & $\mathbf{2 0 1 0}$ & $\mathbf{2 0 1 1}$ & $\mathbf{2 0 1 2}$ & $\mathbf{2 0 1 3}$ & $\mathbf{2 0 1 4}$ \\
\hline No of Cons. & 11 & 13 & 14 & 14 & 21 & 23 & 25 & 30 & 31 \\
\hline Market value & 1,756 & 2,471 & 2,652 & 3,172 & 11,189 & 6,224 & 8,857 & 8,73 & 9,722 \\
\hline
\end{tabular}


As of 31.12.2011, the number of Real Estate Investment Trusts quoted on Borsa Istanbul was 23 and their market value was 6.2 billion \$. By the end of June 2014, the number had increased to 31 with market value increased by $50 \%$ to 9.7 billion \$. However, when thesefigures are analysed in Turkey, it can be concluded that a very small part of real estate financing is transferred through the capital markets.

\section{Literature Review}

There have been a significant number of sectoral studies in domestic and foreign literature implemented using the TOPSIS method, although there have been almost no studies conducted on the REIT Industry using the method. The vast majority of studies in the financial sector are related to banking industry. As we are going to reflect the economic or financial aspect of REITs in this study, we have only reviewed articles in which the financial performance of the firm was assessed using TOPSIS. In other words, non-financial performance criteria were not taken into account in this study.

The TOPSIS method is a MCDM technique which was first proposed by Hwang and Yoon (1981) and later improved by Yoon (1987) and Hwang et al (1993). According to this method, the chosen alternative should have the shortest distance from the positive ideal solution and the longest distance from the negative ideal solution. The ideal solution is identified with a hypothetical alternative that has the best values for all considered attributes whereas the negative ideal solution is identified with a hypothetical alternative that has the worst attribute values (Chamodrakas, Leftheriotis, Martakos, 2011).

Yurdakul and İç (2003) carried out a study on 5 large-scale firms in the Turkish Automotive Industry traded on Borsa Istanbul covering the period 1998-2001. They used financial ratios derived from the balance sheets of the firms and conducted a case study in order to rank these firms using TOPSIS. The market values of these firms were extracted from Stock Data Set of Borsa Istanbul Web Site for each year and compared with those of TOPSIS. The results obtained using TOPSIS were consistent with the market values.

Seçme, Bayrakdaroğlu and Kahraman (2009) proposed a fuzzy multi-criteria decision model to evaluate the performance of 5 leading banks in the Turkish Banking Industry. In the study, the banks were analyzed in terms of several financial and non-financial indicators. Fuzzy Analytic Hierarchy Process (FAHP) and Technique for Order Performance by Similarity to Ideal Solution (TOPSIS) methods were integrated in the proposed model. After the weighting for a number of criteria were determined based on the opinions of experts using the FAHP method, these weights were used as input data when employing the TOPSIS method to rank the banks. The results showed that non-financial performance as well as financial performance should be considered in a competitive environment. Similarly, Ertuğrul and Karakaşoğlu (2009) developed a fuzzy model based on Fuzzy Analytic Hierarchy Process(FAHP) and TOPSIS to evaluate the financial performance of the 15 Turkish Cement Firms traded on Borsa Istanbul (BIST-formerly ISE). In the survey, taking subjective judgments of decision-makers into consideration, FAHP method was used to determine the weighting of the criteria and then the rankings of the firms were determined by the TOPSIS method.

Kıyılar and Hepşen (2010) carried out a study on Performance Appraisal Of Real Estate Investment Trusts (REITs) traded on Borsa Istanbul (formerly ISE). The sample for the study was composed of 8 REITs covering the period between January 2000 and December 2008. In the study, the Sharpe Index and the Jensen Index were employed to measure the performance of each REIT relative to the market portfolio. The results of the study indicated that Pera REIT performed better than the other REIT stocks for both Sharpe and Jensen Indices over the period.

Bulgurcu (2012) conducted a study on assessment of the financial performance of thirteen technology firms trading on Borsa Istanbul covering the period 2009-2011. Ten financial ratios were assigned to calculate the financial performance score of these firms using TOPSIS. According to the findings, the ranking results of TOPSIS and the market values were not similar for the period of 2009-2011.However, the consistent firms in the ranking results of TOPSIS for those years were similar to the firms consistent in the ranking results of market value.

Yayar and Baykara (2012) performed a survey regarding the efficiency and productivity of participating bank activities between 2005-2011 within the financial system in Turkey. Based on the financial ratios derived from the financial data, banks were subject to outranking. According to analysis results, Albaraka Turk was defined as the most efficient and Bank Asya as the most productive. In parallel with the diversification of Kuveyt Turk financial instruments, there was an appreciable increase in efficiency and productivity.

Akkoç and Vatansever (2013) examined the financial performance of 12 commercial banks traded on Borsa Istanbul using the Fuzzy Analytic Hierarchy Process (FAHP) and Fuzzy TOPSIS methods. In the study, the financial performance of the banks was measured with 17 financial ratios classified under 7 mean categories and the asset size 
of 12 commercial banks which wereincluded in theanalysis constituted $78 \%$ of the asset size of commercial banks in Turkey. The dataset covered the financial ratios of the banks for the year 2010 which corresponded to after the 2008 global crisis. Despite small differences in scores, the empirical results concerning the first 5 banks were the same in the Fuzzy AHP and Fuzzy TOPSIS methods.

Kazan and Ozdemir (2014) analyzed the financial statements of 14 large-scale conglomerates traded on Borsa Istanbul using the TOPSIS method. In the first phase, in order to determine the weighting of the criteria objectively, the Critic Method, which was originally proposed by Diakoulaki et al. (1995), was used to calculate 19 financial ratios of these holdings over three periods (2009-2011). The TOPSIS method was applied to the 19 financial ratios and thus the financial performance score of conglomerates were computed. The financial performance scoresof the observed ranked conglomerates showed that the best performance was in TAV Airports Holding with an average of 95.6\% for the years 2009-2011, and the worst performance was in DYHOL, with average $48.3 \%$.

In a study by Mandic, Delibasic, Knezevic and Benkovic (2014) a fuzzy multi-criteria model was proposed to facilitate the assessment of the financial performance of banks. Methods such as FAHP and TOPSIS were integrated into the proposed model. By applying the model, analysis was applied to the Serbian Banking Industry covering the period 2005-2010. First, the priority weighting of criteria were determined using FAHP and then ranking of the banks was performed through the application of the TOPSIS method. Following the research based on selected financial categories (Equity, Portfolio, Sources, Liquid Assets, Cash, Net Interest Income, Core Business Net Income and Earnings Before Tax) in the process of evaluation of the financial parameters of the Serbian banks, the criteria of Equity and EBT proved to be the most significant. Based on financial categories, the banks were analyzed through the use of the TOPSIS method and Banca Intesa was observed to have the best rating among the ranked banks.

In the survey conducted by Wang and Wang (2014), the financial performance of Taiwan container shipping companies were evaluated by the fuzzy multi-criteria decision-making method, TOPSIS. Grey relation analysis, which was first introduced by Julong (1989), was applied to partition financial ratios into several categories (financial structure, solvency, turnover, profitability) and to find representative indices from the categories. The representative indices were then considered as evaluation criteria in the financial performance assessment of Taiwan container shipping companies. Using fuzzy TOPSIS, the companies were ranked in accordance with their financial performance.

A recent study was performed by Önder, Taş and Hepşen (2014) assessing the financial performance of REITs in Turkey using Analytical Network Process (ANP) and TOPSIS methodologies. In the study, 24 publicly traded REITs were subject to financial performance analysis and outranking during Sep 2012-Sep 2013. The financial performance of the firms was subdivided into eight groups of Asset Growth Rate, Operating Costs / Net Sales, Return on Asset, Net Profit Margin, Return on Equity, Current Ratio, Long Term Assets / Total Assets and Quick Ratio. After ANP and correlation analysis, the most important ratios and their weighting were found to be Return on Equity (0.183), Return on Asset (0.171), Net Profit Margin (0.171) and Long Term Assets / Total Assets (0.134). Finally, the TOPSIS method was applied to rank the REITs and according to empirical results, Akmerkez REIT was the best financial performing REIT and its market value was relatively low while Özderici REIT was one of the worst financially performing REITs and its market value was relatively high.

\section{Data and Methodology}

25 private and public equity companies publiclytraded on the Borsa Istanbul (BIST) for which the financial statements are available for 15 quarters from 2011Q1 to 2014Q3 were identified in order to assess REIT financial performance. The financial performance of Akfen REIT ( AKFGY), Ata REIT (ATAGY), Atakule REIT (ATAGY), Avrasya REIT (AVGYO), Deniz REIT (DNZGYO), Doğuş REIT (DGGYO), Emlak Konut REIT (EKGYO), Halk REIT (HLGYO), İdealist REIT (IDGYO), İş REIT (ISGYO), Kiler REIT (KLGYO), Nurol REIT (NUGYO), Özderici REIT (OZGYO), Pera REIT (PEGYO), Reysaş REIT (REGYO), Saf REIT (SAFGY), Servet REIT (SRVGY), Sinpaş REIT (SNGYO), Torunlar REIT (TRGYO), TSKB REIT (TSGYO), Vakıf REIT (VKGYO), Yapı Kredi Koray REIT (YKGYO), Yeşil REIT (YGYO) will be analyzed through this study.

The data for the study was obtained from the financial statements on the public disclosure platform website (www.kap.gov.tr). 16 financial ratios were determined to assess the REIT financial performance scores. Within this framework, the research data is based on 6000 observations comprising 16 financial ratios from 15 quarters related to 25 REITs.

The performance criteria and content used to analyze the REIT financial performance are presented in Table 4. 
Table 4. Definitions of performance criteria of REITs

\begin{tabular}{|c|c|c|c|c|c|}
\hline Group & Code & Performance Criteria & Definitions of Criteria & Ideal Value & Optimum \\
\hline \multirow{3}{*}{ Liquidity } & LKO1 & Current Ratio (\%) & Current Assets/Short Term Liabilities & $\begin{array}{l}\text { 1.5-2.0 ideal and } \\
\text { distance to } 1.75\end{array}$ & Minimum \\
\hline & LK02 & Asit Test Ratio (\%) & (Current Assets-Inventories)/Short Term Liabilities & Distance to 1.00 . & Minimum \\
\hline & LK03 & Cash Ratio (\%) & (Liquid Assets+Securities)/ Short Term Liabilities & Distance to 0.20 . & Minimum \\
\hline \multirow{3}{*}{ Leverage } & FYO1 & Financial Leverage Ratio (\%) & Liabilities/Total Assets & Distance to 0.60 & Minimum \\
\hline & FYO2 & Investment Ratio (\%) & Fixed Assets / Permanent Capital & - & Maximum \\
\hline & FYO3 & Debt to Equity Ratio (\%) & Liabilities/ Equity & - & Minimum \\
\hline \multirow{5}{*}{$\begin{array}{l}\text { Asset and } \\
\text { Capital } \\
\text { Structure }\end{array}$} & VSY1 & Current Assets/Total Assets (\%) & Current Assets/Total Assets & $\begin{array}{l}0.30-0.40 \text { ideal and } \\
\text { distance to } 0.35 \text {. }\end{array}$ & Minimum \\
\hline & VSY2 & Fixed Assets/Total Assets (\%) & Fixed Assets/Total Assets Ratio & $\begin{array}{l}0.60-0.70 \text { ideal and } \\
\text { distance to } 0.65 \text {. }\end{array}$ & Minimum \\
\hline & VSY3 & Short Term Liabilities /Total Assets (\%) & Short Term Liabilities /Total Assets & - & Minimum \\
\hline & VSY4 & Long Term Liabilities /Total Assets (\%) & Long Term Liabilities /Total Assets & - & Maximum \\
\hline & VSY5 & Equity/Assets Ratio (\%) & Equity/Assets & - & Maximum \\
\hline \multirow{3}{*}{ Turnover } & F01 & Asset Turnover Ratio (\%) & Net Sales/Total Assets & - & Maximum \\
\hline & F02 & Equity Turnover Ratio (\%) & Net Sales/Equity & - & Maximum \\
\hline & F03 & Working Capital Turnover Ratio(\%) & Net Sales/Net Working Capital & - & Maximum \\
\hline \multirow{2}{*}{ Profitability } & KO1 & Return on Assets (\%) & Net Income/Total Assets & - & Maximum \\
\hline & KO2 & Return on Equity (\%) & Net Income/Equity & - & Maximum \\
\hline
\end{tabular}

The financial ratios used in the study were selected from those which could provide information about the liquidity position, financial structure, equity structure, activity performance and profitability figures of the company. A restriction was encountered while measuring the net margin profit due to the fact that the companies in the sector work on a project basis and therefore current projects have been completed and new projects have not been started but the sale amount is not included in the main activity. Therefore, financial ratios created in harmony with the sector's structure were determined at the ideal values and optimum levels according to the structure of the research method.

In the measurement of REIT performance, the importance level of each criterion for the multi-criteria decision making problem may not be the same. In this respect, a weighting value must be attached to each criterion to measure the different importance levels. Afterwards, the TOPSIS method shall be applied to the criteria weighted with the entropy method.

\subsection{Entropy Method}

Entropy is one of the most widely used objective weighting methods. If the data of the decision matrix is available then, the entropy method can be very useful to evaluate the weighting (Deng, 2000). The entropy concept was defined as a measure of uncertainty by Shannon and Weaver (1949). The decision matrix for a MCDM problem comprises a definite quantity of information; entropy can be utilized as an implement in criteria evaluation(Zeleny, 1974; Nijkamp, 1977).

The entropy method consists of the following steps:

Eq. (1) shows decision matrix $D$ of a multi-criteria problem with $m$ alternatives and $n$ criteria,

$$
D=\begin{gathered}
X_{1} X_{2} \cdots \\
A_{1} \\
A_{2} \\
\vdots \\
A_{m}
\end{gathered}\left[\begin{array}{cccc}
x_{11} & x_{12} & \ldots & x_{1 n} \\
x_{21} & x_{22} & \ldots & x_{2 n} \\
\vdots & \vdots & \vdots & \vdots \\
x_{m 1} & x_{m 2} & \ldots & x_{m n}
\end{array}\right]
$$

where $x_{i j}$ is the achievement value of the $i$ th alternative for the $j$ th criterion.

Step 1: $R=\left[r_{i j}\right]_{m \times n}$ normalized decision matrix calculated by the following formula: 


$$
r_{i j}=\frac{x_{i j}}{\sum_{p=1}^{m} x_{p j}}, i=1,2, \ldots, m, j=1,2, \ldots, n
$$

The aim of the normalization is to obtain same scale for all criteria and so to make comparison between them (Çalışkan, 2013).

Step 2:

$$
e_{j}=-K \sum_{i=1}^{m} r_{i j} \ln r_{i j}, \quad j=1,2, \ldots, n
$$

The entropy value $e_{j}$ for $j$ th criterion is obtained via theformula above. Where $K$ is a constant number: $K=\frac{1}{\ln m}$ which assures that $0 \leq e_{j} \leq 1$.

Step 3: The degree of diversification $d_{j}$ of the average information contained by the outcomes of criterion $j$ can be obtained as

$$
d_{j}=1-e_{j}, j=1,2, \ldots, n
$$

Step 4: Finally, the weight of $j$ th criterion can be defined as:

$$
W_{j}=\frac{1-e_{j}}{\sum_{p=1}^{n}\left(1-e_{p}\right)}, j=1,2, \ldots, n .
$$

as addition $\sum_{j=1}^{n} W_{j}=1$ is clear.

\subsection{TOPSIS Method}

In this paper,we applied the TOPSIS (Technique for Order Preference by Similarity to Ideal Solution) as MCDM method. The basic idea of the TOPSIS method is used to obtain a solution, which is closest to the ideal solution and farthest from the negative ideal solution. The TOPSIS assumed that each attribute takes the monotonically increasing (or decreasing) utility; then it is very simple to determine the "ideal" solution which consists of all the best criteria values reachable, and the "negative-ideal" solution consisting of all the worst criteria values reachable (Hwang and Yoon,1981). The TOPSIS procedure consists of the following steps:

Step 1: The normalization of the decision matrix is performed using Eq. (6)

$$
r_{i j}=\frac{x_{i j}}{\sqrt{\sum_{i=1}^{m} x_{i j}^{2}}} \quad i=1,2, \ldots, n ; j=1,2, \ldots, m .
$$

thus the normalized decision matrix $R=\left[r_{i j}\right]_{m \times n}$ is obtained.

Step 2: The columns of normalized matrix $R$ multiplied by the related weights, $W_{j}$, obtained in Eq. (5) and values of the weighted and normalized decision matrix are calculated by the following equation:

$$
V_{i j}=W_{j} r_{i j}, i=1,2, \ldots \ldots, m ; j=1,2, \ldots \ldots, n .
$$

Step 3: The ideal solution $A^{+}$and negative-ideal solution $A^{-}$are determined using Eqs. (8) and (9), respectively:

$$
\begin{aligned}
& V_{j}^{+}=\left\{\left(\max _{i j} \mid j \in J\right),\left(\operatorname{minv}_{i j} \mid j \in J^{\prime}\right) \mid i=1,2, \ldots, m\right\} \\
& V_{j}^{-}=\left\{\left(\operatorname{minv}_{i j} \mid j \in J\right),\left(\max _{i j} \mid j \in J^{\prime}\right) \mid i=1,2, \ldots, m\right\}
\end{aligned}
$$

where $J$ and $J^{\prime}$ are index sets of benefit and cost criteria respectively. Thus $A^{+}=\left\{V_{1}^{+}, V_{2}^{+}, \ldots \ldots, V_{n}^{+}\right\}$and $A^{-}=$ $\left\{V_{1}^{-}, V_{2}^{-}, \ldots \ldots, V_{n}^{-}\right\}$are obtained.

Step 4: The distances from the ideal and anti-ideal solutions are calculated for each alternatives using the two Euclidean distances as given in Eqs. (10) and (11), respectively

$$
\begin{aligned}
& \left(S_{i}^{+}\right)=\sqrt{\sum_{j=1}^{n}\left(V_{i j}-V_{j}^{+}\right)^{2}}, i=1,2, \ldots \ldots, m ; \\
& \left(S_{i}^{-}\right)=\sqrt{\sum_{j=1}^{n}\left(V_{i j}-V_{j}^{-}\right)^{2}}, i=1,2, \ldots \ldots, m ;
\end{aligned}
$$

Step 5: The relative closeness to the ideal solution $C_{i}^{+}$is computed as shown in the following equation:

$$
C_{i}^{+}=\frac{s_{i}^{-}}{S_{i}^{-}+S_{i}^{+}}, i=1,2, \ldots \ldots, m ; 0 \leq C_{i}^{+} \leq 1
$$

The higher values of $C_{i}^{+}$indicate that the rank is better. 


\section{Results of Empirical Analysis}

In the framework of the analysis, the financial performance ratios for the period 2011Q1 -2014Q3 were calculated separately and used to assess the company's financial performance. On the other hand, the general performance scores were converted into a unique score by the TOPSIS method and using the entropy weighting. In this framework, the task of financial performance assessment was completed by ranking the REITs. To provide an example, the TOPSIS method will be gradually applied and the other ranking results will be aggregated in the final result.

\subsection{The Setting of the Decision Matrix}

The REITs that have decision points, the superiority of which has to be determined through the constituted decision matrix lines while in the columns, occur in the financial performance ratios which are the evaluation factors. 25 decision points (REITs) and 16 evaluation factors (financial performance ratios) were used in the research. First, the Standard Decision Matrix was set with the dimensions (25x 16) for the TOPSIS method obtained from the REITs. The decision matrix for the period 2014Q3 related to the REIT subjects of the research is presented in Table 5 .

Table 5. Decision matrix (2014Q3)

\begin{tabular}{|c|c|c|c|c|c|c|c|c|c|c|c|c|c|c|c|c|}
\hline \multirow[b]{2}{*}{ REITs } & \multicolumn{16}{|c|}{ Criteria } \\
\hline & LK01 & LK02 & LK03 & FY01 & FY02 & FY03 & VSY1 & VSY2 & VSY3 & VSY4 & VSY5 & F01 & F02 & F03 & K01 & K02 \\
\hline Akfen & 1.287 & 0.537 & 0.094 & 0.208 & 1.042 & 0.644 & 0.316 & 0.316 & 0.073 & 0.319 & 0.608 & 0.025 & 0.040 & -0.628 & 0.014 & 0.023 \\
\hline Akmerkez & 9.371 & 10.121 & 10.225 & 0.579 & 0.794 & 0.021 & 0.128 & 0.128 & 0.020 & 0.001 & 0.979 & 0.332 & 0.339 & 1.644 & 0.254 & 0.259 \\
\hline Alarko & 98.050 & 89.831 & 84.575 & 0.593 & 0.461 & 0.007 & 0.192 & 0.192 & 0.005 & 0.002 & 0.993 & 0.034 & 0.034 & 0.063 & 0.054 & 0.055 \\
\hline Atakule & 82.192 & 82.942 & 82.829 & 0.591 & 0.753 & 0.009 & 0.101 & 0.101 & 0.003 & 0.006 & 0.991 & 0.021 & 0.021 & 0.084 & 0.038 & 0.038 \\
\hline Avrasya & 4.744 & 5.494 & 1.193 & 0.504 & 0.754 & 0.106 & 0.072 & 0.072 & 0.043 & 0.053 & 0.904 & 0.108 & 0.120 & 0.460 & 0.013 & 0.014 \\
\hline Deniz & 10.593 & 11.343 & 11.503 & 0.593 & 0.930 & 0.007 & 0.274 & 0.274 & 0.006 & 0.001 & 0.993 & 0.504 & 0.507 & 7.230 & 0.020 & 0.020 \\
\hline Doğuş & 0.504 & 1.254 & 1.956 & 0.465 & 0.963 & 0.156 & 0.285 & 0.285 & 0.029 & 0.106 & 0.865 & 0.047 & 0.054 & 1.280 & 0.035 & 0.041 \\
\hline Emlak Konut & 0.942 & 0.274 & 0.317 & 0.176 & 1.122 & 0.736 & 0.037 & 0.037 & 0.388 & 0.036 & 0.576 & 0.095 & 0.164 & -1.266 & 0.050 & 0.086 \\
\hline İdealist & 558.101 & 70.697 & 25.131 & 0.598 & 0.001 & 0.002 & 0.649 & 0.649 & 0.002 & 0.000 & 0.998 & 0.000 & 0.000 & 0.000 & -0.027 & -0.028 \\
\hline İş & 3.324 & 3.970 & 2.579 & 0.254 & 0.868 & 0.529 & 0.190 & 0.190 & 0.031 & 0.315 & 0.654 & 0.109 & 0.167 & 0.850 & 0.033 & 0.050 \\
\hline Kiler & 0.058 & 0.011 & 0.178 & 0.097 & 0.743 & 1.014 & 0.086 & 0.086 & 0.241 & 0.262 & 0.497 & 0.077 & 0.155 & 0.395 & -0.007 & -0.014 \\
\hline Nurol & 0.638 & 0.836 & 0.194 & 0.353 & 0.578 & 20.329 & 0.529 & 0.529 & 0.790 & 0.163 & 0.047 & 0.005 & 0.104 & 0.055 & -0.004 & -0.075 \\
\hline Özderici & 4.035 & 0.254 & 0.153 & 0.185 & 0.166 & 0.710 & 0.509 & 0.509 & 0.148 & 0.267 & 0.585 & 0.016 & 0.028 & 0.023 & 0.071 & 0.122 \\
\hline Pera & 1.456 & 0.714 & 0.172 & 0.287 & 1.196 & 0.456 & 0.286 & 0.286 & 0.217 & 0.096 & 0.687 & 0.027 & 0.039 & -0.176 & -0.026 & -0.038 \\
\hline Reysaş & 0.212 & 0.962 & 0.904 & 0.159 & 0.893 & 0.789 & 0.154 & 0.154 & 0.100 & 0.341 & 0.559 & 0.054 & 0.097 & 0.565 & 0.008 & 0.014 \\
\hline Saf & 0.943 & 0.559 & 0.043 & 0.191 & 1.020 & 0.692 & 0.273 & 0.273 & 0.095 & 0.314 & 0.591 & 0.250 & 0.423 & -13.631 & 0.518 & 0.877 \\
\hline Servet & 1.579 & 0.829 & 0.056 & 0.143 & 1.679 & 0.841 & 0.273 & 0.273 & 0.450 & 0.007 & 0.543 & 0.058 & 0.106 & -0.154 & 0.011 & 0.020 \\
\hline Sinpaş & 0.068 & 0.012 & 0.097 & 0.100 & 0.612 & 0.999 & 0.235 & 0.235 & 0.322 & 0.178 & 0.500 & 0.171 & 0.341 & 0.648 & 0.018 & 0.037 \\
\hline TSKB & 0.825 & 0.075 & 0.500 & 0.173 & 1.004 & 0.744 & 0.308 & 0.308 & 0.046 & 0.381 & 0.573 & 0.037 & 0.065 & -10.984 & 0.004 & 0.006 \\
\hline Vakıf & 322.564 & 323.314 & 320.474 & 0.597 & 0.289 & 0.003 & 0.362 & 0.362 & 0.002 & 0.001 & 0.997 & 0.003 & 0.003 & 0.005 & 0.026 & 0.027 \\
\hline Yapı Kredi & 0.853 & 0.768 & 0.077 & 0.206 & 1.284 & 4.163 & 0.309 & 0.309 & 0.735 & 0.072 & 0.194 & 0.251 & 1.297 & -3.327 & -0.086 & -0.442 \\
\hline Yeşil & 1.956 & 0.840 & 0.196 & 0.178 & 0.343 & 3.506 & 0.374 & 0.374 & 0.195 & 0.583 & 0.222 & 0.003 & 0.014 & 0.006 & -0.015 & -0.067 \\
\hline
\end{tabular}

\subsection{Weighting of Criteria through the Entropy Method}

The weighted value of every criterion was calculated by the entropy method and is shown in Table 6. As may be seen in the table, LK01, LK02 and LK02 have taken a relatively higher criterion value than the other criteria. The reason for this is that in some parts of the companies in the analysis, the share of current assets in the total assets is very high. For example, İdealist, Vakıf, Alarko and Atakule respectively take excessively high values, while 
companies such as Torunlar, Halk and Kiler have quite low values. No abnormal case was observed among the other criterion weighting. Only the VSY5 criterion weighting was low. The reason for this is that the companies under the criteria have values very close to each other and the fact that proportionally there was no excessively low or high figure.

Table 6. Entropy weights (2014Q3)

\begin{tabular}{lcccccccc}
\hline Ratios & LK01 & LK02 & LK03 & FY01 & FY02 & FY03 & VSY1 & VSY2 \\
\hline Weights & 0.149 & 0.139 & 0.150 & 0.013 & 0.010 & 0.109 & 0.013 & 0.013 \\
\hline Ratios & VSY3 & VSY4 & VSY5 & F01 & F02 & F03 & K01 & K02 \\
\hline Weights & 0.052 & 0.043 & 0.007 & 0.048 & 0.057 & 0.075 & 0.057 & 0.065 \\
\hline
\end{tabular}

\subsection{The Setting of the Weighted Normalized Decision Matrix}

By determining the weightings related to the evaluation factors via the entropy method, the weighted normalized values are found by multiplying the pre-calculated normalized values. The REIT normalized weighted decision matrix prepared for the period 2014Q3 is presented in Table 7.

\subsection{Ranking of Similarity with the Ideal Solution}

In order to be able to rank the REITs for the period 2014Q3, the solution sets of positive ideal $A^{+}$and negative ideal $A^{-}$are first constituted. The positive ideal values are created by choosing the maximum value for benefit criterion or minimum value for cost criterionon each column of the $V$ matrix for the set $A^{+}$. Similarly, the negative ideal values are created by choosing the minimum value for benefit criterion or maximum value for cost criterion of every column on the $V$ matrixfor the set $A^{-}$. These values are presented in Table 8 .

The positive discrimination $S^{+}$values and the negative discrimination $S^{-}$values were calculated using the negative ideal and positive ideal values of the REIT. According to the results, the scores $C^{+}$of similarity with the REIT ideal set for 2014Q3 were obtained. The maximum of these $C^{+}$scores was determined as the first one in the ranking and the REIT scores of similarity to the solution set were ranked in this way. The REIT ranking for 2014Q3 is presented in Table 9.

Table 7. Weighted normalized decision matrix (2014Q3)

\begin{tabular}{|c|c|c|c|c|c|c|c|c|c|c|c|c|c|c|c|c|}
\hline REITs & LK01 & LK02 & LK03 & FY01 & FY02 & FY03 & VSY1 & VSY2 & VSY3 & VSY4 & VSY5 & F01 & F02 & F03 & K01 & K02 \\
\hline Akfen & 0.000 & 0.000 & 0.000 & 0.001 & 0.002 & 0.003 & 0.003 & 0.003 & 0.003 & 0.012 & 0.001 & 0.002 & 0.001 & -0.002 & 0.000 & 0.000 \\
\hline Akmerkez & 0.002 & 0.004 & 0.004 & 0.004 & 0.002 & 0.000 & 0.001 & 0.001 & 0.001 & 0.000 & 0.002 & 0.021 & 0.012 & 0.004 & 0.009 & 0.005 \\
\hline Alarko & 0.022 & 0.035 & 0.037 & 0.004 & 0.001 & 0.000 & 0.002 & 0.002 & 0.000 & 0.000 & 0.002 & 0.002 & 0.001 & 0.000 & 0.002 & 0.001 \\
\hline Ata & 0.000 & 0.000 & 0.000 & 0.003 & 0.002 & 0.001 & 0.003 & 0.003 & 0.001 & 0.005 & 0.002 & 0.001 & 0.001 & 0.005 & -0.002 & -0.001 \\
\hline Avrasya & 0.001 & 0.002 & 0.001 & 0.004 & 0.002 & 0.001 & 0.001 & 0.001 & 0.002 & 0.002 & 0.002 & 0.007 & 0.004 & 0.001 & 0.000 & 0.000 \\
\hline Deniz & 0.002 & 0.004 & 0.005 & 0.004 & 0.002 & 0.000 & 0.002 & 0.002 & 0.000 & 0.000 & 0.002 & 0.032 & 0.018 & 0.017 & 0.001 & 0.000 \\
\hline Doğuş & 0.000 & 0.000 & 0.001 & 0.003 & 0.002 & 0.001 & 0.002 & 0.002 & 0.001 & 0.004 & 0.002 & 0.003 & 0.002 & 0.003 & 0.001 & 0.001 \\
\hline Emlak Konut & 0.000 & 0.000 & 0.000 & 0.001 & 0.002 & 0.004 & 0.000 & 0.000 & 0.015 & 0.001 & 0.001 & 0.006 & 0.006 & -0.003 & 0.002 & 0.002 \\
\hline İdealist & 0.127 & 0.028 & 0.011 & 0.004 & 0.000 & 0.000 & 0.006 & 0.006 & 0.000 & 0.000 & 0.002 & 0.000 & 0.000 & 0.000 & -0.001 & -0.001 \\
\hline İş & 0.001 & 0.002 & 0.001 & 0.002 & 0.002 & 0.003 & 0.002 & 0.002 & 0.001 & 0.012 & 0.001 & 0.007 & 0.006 & 0.002 & 0.001 & 0.001 \\
\hline Kiler & 0.000 & 0.000 & 0.000 & 0.001 & 0.002 & 0.005 & 0.001 & 0.001 & 0.009 & 0.010 & 0.001 & 0.005 & 0.006 & 0.001 & 0.000 & 0.000 \\
\hline Nurol & 0.000 & 0.000 & 0.000 & 0.002 & 0.001 & 0.104 & 0.005 & 0.005 & 0.030 & 0.006 & 0.000 & 0.000 & 0.004 & 0.000 & 0.000 & -0.001 \\
\hline Özderici & 0.001 & 0.000 & 0.000 & 0.001 & 0.000 & 0.004 & 0.004 & 0.004 & 0.006 & 0.010 & 0.001 & 0.001 & 0.001 & 0.000 & 0.002 & 0.002 \\
\hline Pera & 0.000 & 0.000 & 0.000 & 0.002 & 0.003 & 0.002 & 0.002 & 0.002 & 0.008 & 0.004 & 0.001 & 0.002 & 0.001 & 0.000 & -0.001 & -0.001 \\
\hline Reysaş & 0.000 & 0.000 & 0.000 & 0.001 & 0.002 & 0.004 & 0.001 & 0.001 & 0.004 & 0.013 & 0.001 & 0.003 & 0.003 & 0.001 & 0.000 & 0.000 \\
\hline Saf & 0.000 & 0.000 & 0.000 & 0.001 & 0.002 & 0.004 & 0.002 & 0.002 & 0.004 & 0.012 & 0.001 & 0.016 & 0.015 & -0.033 & 0.018 & 0.017 \\
\hline
\end{tabular}




\begin{tabular}{|c|c|c|c|c|c|c|c|c|c|c|c|c|c|c|c|c|}
\hline Servet & 0.000 & 0.000 & 0.000 & 0.001 & 0.004 & 0.004 & 0.002 & 0.002 & 0.017 & 0.000 & 0.001 & 0.004 & 0.004 & 0.000 & 0.000 & 0.000 \\
\hline Sinpaş & 0.000 & 0.000 & 0.000 & 0.001 & 0.001 & 0.005 & 0.002 & 0.002 & 0.012 & 0.007 & 0.001 & 0.011 & 0.012 & 0.002 & 0.001 & 0.001 \\
\hline Torunlar & 0.000 & 0.000 & 0.000 & 0.000 & 0.002 & 0.006 & 0.001 & 0.001 & 0.005 & 0.015 & 0.001 & 0.005 & 0.006 & 0.002 & 0.001 & 0.001 \\
\hline TSKB & 0.000 & 0.000 & 0.000 & 0.001 & 0.002 & 0.004 & 0.003 & 0.003 & 0.002 & 0.014 & 0.001 & 0.002 & 0.002 & -0.026 & 0.000 & 0.000 \\
\hline Vakıf & 0.073 & 0.127 & 0.140 & 0.004 & 0.001 & 0.000 & 0.003 & 0.003 & 0.000 & 0.000 & 0.002 & 0.000 & 0.000 & 0.000 & 0.001 & 0.001 \\
\hline Yapı Kredi & 0.000 & 0.000 & 0.000 & 0.001 & 0.003 & 0.021 & 0.003 & 0.003 & 0.028 & 0.003 & 0.000 & 0.016 & 0.047 & -0.008 & -0.003 & -0.009 \\
\hline Yeşil & 0.000 & 0.000 & 0.000 & 0.001 & 0.001 & 0.018 & 0.003 & 0.003 & 0.007 & 0.022 & 0.000 & 0.000 & 0.001 & 0.000 & -0.001 & -0.001 \\
\hline
\end{tabular}

Table 8. The ideal and negative-ideal solutions (2014Q3)

\begin{tabular}{ccccccccc}
\hline & LK01 & LK02 & LK03 & FY01 & FY02 & FY03 & VSY1 & VSY2 \\
\hline $\mathbf{A}^{+}$ & 0.000005 & 0.000004 & 0.000019 & 0.000487 & 0.003668 & 0.000011 & 0.000321 & 0.000321 \\
\hline $\mathbf{A}^{-}$ & 0.126537 & 0.127242 & 0.140377 & 0.004201 & 0.000001 & 0.103958 & 0.005663 & 0.005663 \\
\hline & & & & & & & & \\
& & & & & & & & \\
\hline & $\mathbf{V S Y 3}$ & $\mathbf{V S Y 4}$ & $\mathbf{V S Y 5}$ & $\mathbf{F 0 1}$ & $\mathbf{F 0 2}$ & $\mathbf{F 0 3}$ & $\mathbf{K 0 1}$ & $\mathbf{K 0 2}$ \\
\hline $\mathbf{A}^{+}$ & 0.000068 & 0.021864 & 0.002071 & 0.032049 & 0.046659 & 0.017268 & 0.017678 & 0.017173 \\
\hline $\mathbf{A}^{-}$ & 0.030163 & 0.000012 & 0.000097 & 0.000000 & 0.000000 & -0.032556 & -0.002917 & -0.008646 \\
\hline
\end{tabular}

Table 9. $S^{+}, S^{-}$and $C^{+},(2014 Q 3)$

\begin{tabular}{lcccc}
\hline REITs & $S^{+}$ & $S^{-}$ & $C^{+}$ & Ranking \\
\hline Akfen & 0.063497952 & 0.252762232 & 0.799222427 & 13 \\
\hline Akmerkez & 0.047399459 & 0.251169378 & 0.841244453 & 2 \\
\hline Alarko & 0.085869325 & 0.207189414 & 0.706989372 & 22 \\
\hline Ata & 0.065012933 & 0.254352438 & 0.796430861 & 16 \\
\hline Atakule & 0.084229837 & 0.210622184 & 0.714331832 & 21 \\
\hline Avrasya & 0.060737716 & 0.252594553 & 0.806155567 & 8 \\
\hline Deniz & 0.043930683 & 0.253895060 & 0.852495347 & 1 \\
\hline Doğuş & 0.062681626 & 0.253832366 & 0.801962542 & 11 \\
\hline Emlak Konut & 0.062455643 & 0.251412622 & 0.801013195 & 12 \\
\hline Halk & 0.064116037 & 0.253486495 & 0.798124917 & 15 \\
\hline İdealist & 0.147069380 & 0.198656867 & 0.574607420 & 24 \\
\hline İs & 0.056356212 & 0.252326817 & 0.817430158 & 4 \\
\hline Kiler & 0.059810716 & 0.251976282 & 0.808168023 & 6 \\
\hline Nurol & 0.125764812 & 0.230107544 & 0.646601344 & 23 \\
\hline Özderici & 0.063454167 & 0.252244444 & 0.799003972 & 14 \\
\hline Pera & 0.066070720 & 0.252365377 & 0.792514981 & 17 \\
\hline Reysaş & 0.060345088 & 0.252677762 & 0.807218264 & 7 \\
\hline Saf & 0.062218356 & 0.253633279 & 0.803013982 & 10 \\
\hline Servet & 0.065737330 & 0.251059432 & 0.792493680 & 18 \\
\hline Sinpaş & 0.053469417 & 0.252186801 & 0.825066812 & 3 \\
\hline Torunlar & 0.056578333 & 0.252349416 & 0.816855775 & 5 \\
\hline TSKB & 0.073654942 & 0.251005739 & 0.773132547 & 20 \\
\hline Vakıf & 0.213982998 & 0.125446958 & 0.369581281 & 25 \\
\hline Yapı Kredi & 0.060028180 & 0.248373339 & 0.805357054 & 9 \\
\hline Yeşil & 0.067214312 & 0.247432927 & 0.786382006 & 19 \\
\hline & & & &
\end{tabular}




\subsection{TOPSIS Scores and Rankings (2011Q1-2014Q3)}

The TOPSIS performance scores and rankings were obtained based on the entropy weightings for the 15 quarterly REIT data sets. Within this framework, the TOPSIS scores for all the periods were ranked from the highest to the lowest. According to the results, the highest score was obtained by Avrasya REIT.

The REIT rankings carried out on the TOPSIS scores basis for any 2011Q1-2014Q3 period was evaluated with regards to the general ranking. Within this ranking, the REIT company with the lowest ranking total value was given the number one. The detailed and general ranking prepared within this framework for the REITs and for all the periods can be seen in Table 10. The TOPSIS scores of the 25 REIT companies for all the periods are shown in detail in Table 11.

Table 10. TOPSIS rankings (2011Q1-2014Q3)

\begin{tabular}{|c|c|c|c|c|c|c|c|c|c|c|c|c|c|c|c|c|}
\hline REITs & 2011Q1 & 2011Q2 & 2011Q3 & 2011Q4 & 2012Q1 & 2012Q2 & $2012 Q 3$ & 2012Q4 & 2013Q1 & 2013Q2 & 2013Q3 & 2013Q4 & 2014Q1 & 2014Q2 & 2014Q3 & $\begin{array}{l}\text { General } \\
\text { Ranking }\end{array}$ \\
\hline Akfen & 6 & 3 & 11 & 12 & 12 & 11 & 14 & 14 & 13 & 14 & 14 & 17 & 15 & 13 & 13 & 12 \\
\hline Akmerkez & 8 & 16 & 4 & 6 & 3 & 4 & 4 & 5 & 2 & 2 & 3 & 5 & 4 & 2 & 2 & 2 \\
\hline Alarko & 18 & 20 & 21 & 20 & 21 & 24 & 22 & 20 & 20 & 22 & 21 & 24 & 21 & 24 & 22 & 23 \\
\hline Ata & 1 & 1 & 1 & 1 & 1 & 1 & 2 & 4 & 25 & 24 & 23 & 20 & 20 & 19 & 16 & 9 \\
\hline Atakule & 20 & 23 & 23 & 22 & 23 & 20 & 23 & 24 & 19 & 19 & 22 & 21 & 23 & 21 & 21 & 24 \\
\hline Avrasya & 2 & 2 & 2 & 2 & 2 & 2 & 1 & 1 & 1 & 1 & 1 & 1 & 12 & 7 & 8 & 1 \\
\hline Deniz & 25 & 21 & 25 & 25 & 25 & 25 & 25 & 25 & 4 & 25 & 25 & 3 & 14 & 1 & 1 & 20 \\
\hline Doğuş & 17 & 19 & 19 & 19 & 17 & 19 & 17 & 17 & 18 & 18 & 16 & 16 & 10 & 11 & 11 & 18 \\
\hline Emlak Konut & 13 & 18 & 6 & 14 & 16 & 15 & 6 & 2 & 5 & 13 & 17 & 10 & 9 & 15 & 12 & 11 \\
\hline Halk & 23 & 12 & 16 & 13 & 14 & 23 & 13 & 9 & 14 & 12 & 12 & 15 & 13 & 12 & 15 & 16 \\
\hline İdealist & 24 & 24 & 24 & 24 & 22 & 22 & 24 & 22 & 24 & 21 & 20 & 25 & 25 & 23 & 24 & 25 \\
\hline İş & 10 & 8 & 12 & 10 & 6 & 7 & 9 & 10 & 9 & 8 & 4 & 4 & 6 & 8 & 4 & 5 \\
\hline Kiler & 3 & 4 & 3 & 4 & 8 & 13 & 8 & 7 & 6 & 5 & 9 & 11 & 11 & 9 & 6 & 4 \\
\hline Nurol & 21 & 14 & 8 & 15 & 18 & 18 & 19 & 23 & 23 & 23 & 24 & 23 & 24 & 22 & 23 & 22 \\
\hline Özderici & 22 & 25 & 20 & 21 & 24 & 16 & 16 & 16 & 16 & 15 & 15 & 12 & 17 & 14 & 14 & 19 \\
\hline Pera & 12 & 6 & 15 & 16 & 13 & 3 & 18 & 15 & 15 & 7 & 8 & 8 & 16 & 16 & 17 & 13 \\
\hline Reysaş & 11 & 7 & 13 & 9 & 7 & 8 & 3 & 8 & 8 & 9 & 10 & 9 & 8 & 10 & 7 & 7 \\
\hline Saf & 7 & 15 & 22 & 3 & 15 & 12 & 15 & 19 & 17 & 16 & 18 & 19 & 2 & 3 & 10 & 15 \\
\hline Servet & 5 & 10 & 17 & 18 & 11 & 9 & 11 & 3 & 12 & 10 & 11 & 18 & 18 & 17 & 18 & 14 \\
\hline Sinpaş & 15 & 9 & 5 & 7 & 4 & 5 & 5 & 6 & 7 & 4 & 7 & 7 & 5 & 5 & 3 & 3 \\
\hline Torunlar & 9 & 11 & 9 & 11 & 10 & 10 & 10 & 13 & 11 & 11 & 13 & 14 & 3 & 4 & 5 & 8 \\
\hline TSKB & 4 & 5 & 7 & 8 & 5 & 6 & 7 & 11 & 10 & 6 & 2 & 13 & 7 & 6 & 20 & 6 \\
\hline Vakıf & 14 & 13 & 10 & 23 & 19 & 17 & 21 & 21 & 22 & 17 & 19 & 22 & 22 & 25 & 25 & 21 \\
\hline Yapı Kredi & 19 & 17 & 18 & 17 & 9 & 14 & 12 & 12 & 3 & 3 & 6 & 6 & 1 & 18 & 9 & 10 \\
\hline Yeşil & 16 & 22 & 14 & 5 & 20 & 21 & 20 & 18 & 21 & 20 & 5 & 2 & 19 & 20 & 19 & 17 \\
\hline
\end{tabular}




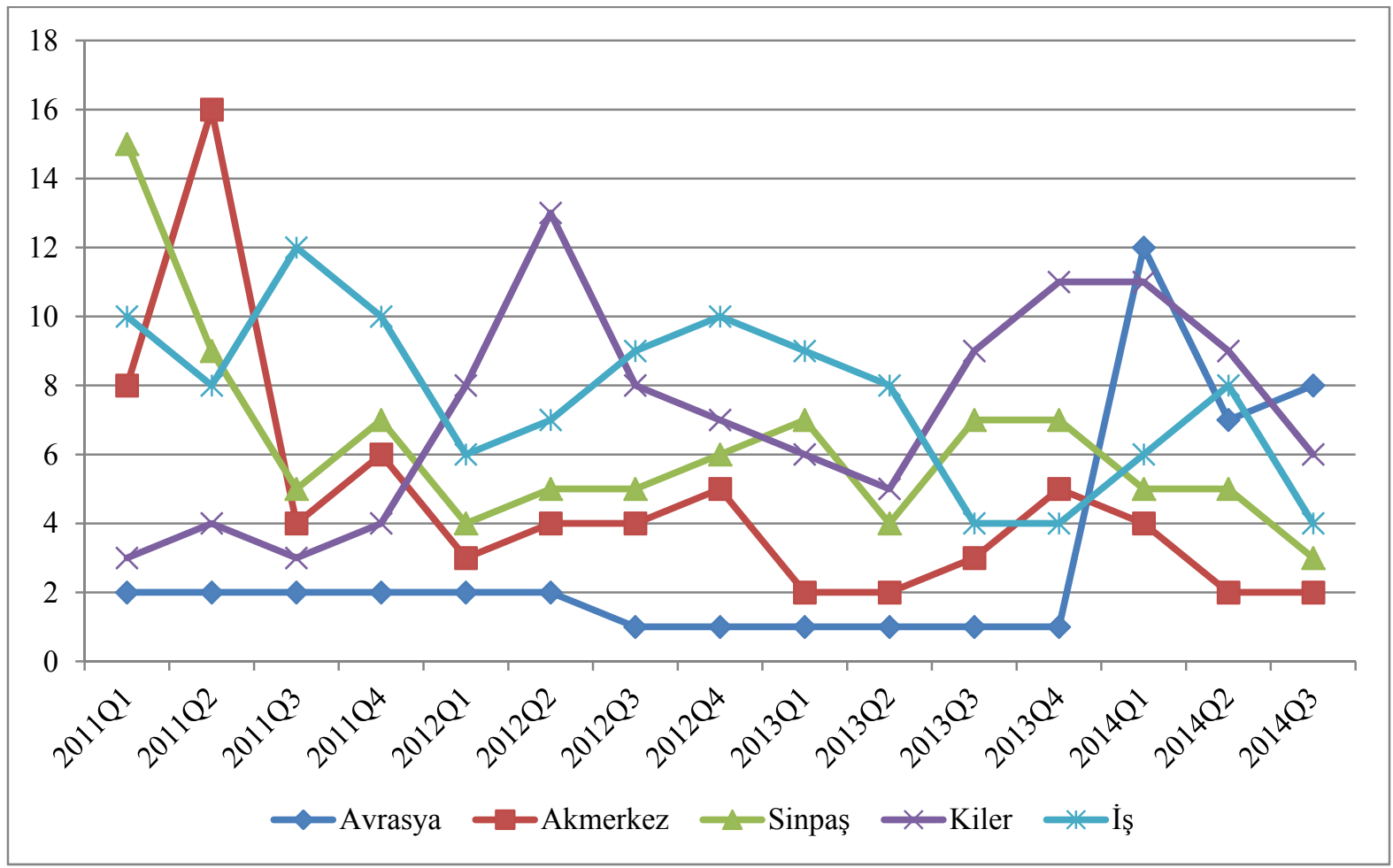

Figure 2. The top five companies ranked by TOPSIS for all the periods

If the financial performance of the companies is evaluated for the analyzed 15 periods based on TOPSIS ranking, Avrasya, Akmerkez, Sinpaş, Kiler and İş companies are seen to have the highest performance respectively. As seen in Figure 2, except for the year 2014 (2014Q1 in particular) Avrasya REIT performs well in all the periods. While Akmerkez Sinpaş and İş showed an increasingly successful performance, Kiler even underperformed during some periods (2012Q2) but reached high performance in general.

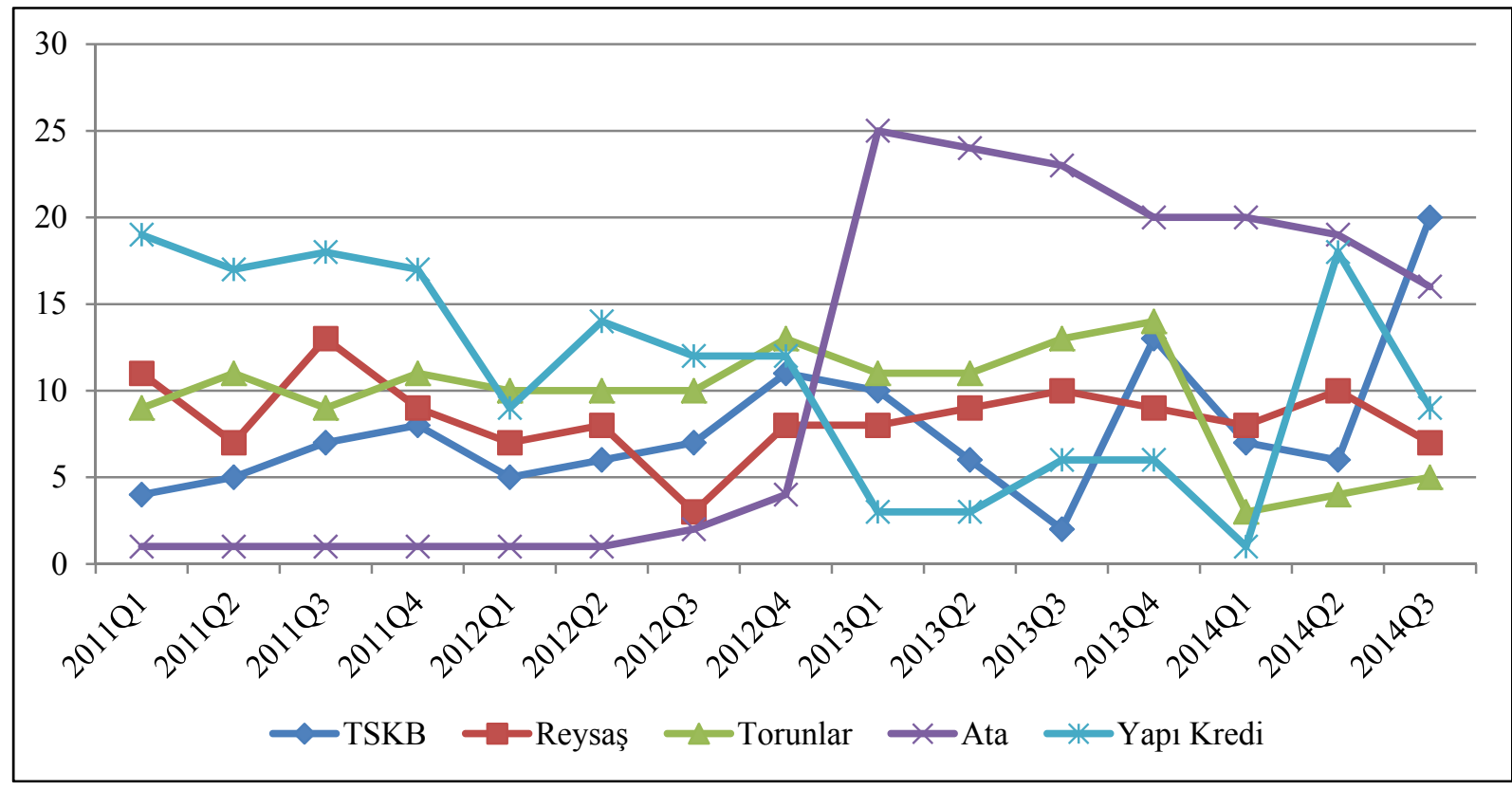

Figure 3. The second best five companies ranked by TOPSIS for all the periods 
The performance ranking of the second best five companies for all the periods is shown in Figure 3 as follows: TSKB, Reysaş, Torunlar, Ata and Yapı Kredi. The TSKB, Reysaş and Torunlar companies show in general a steady performance on the same level, while Ata, after showing a very good performance until 2013Q1, slipped dramatically thereafter.

Table 11. TOPSIS scores (2011Q1-2014Q3)

\begin{tabular}{|c|c|c|c|c|c|c|c|c|c|c|c|c|c|c|c|c|}
\hline REITs & 2011Q1 & 2011Q2 & 2011Q3 & 2011Q4 & 2012Q1 & 2012Q2 & 2012Q3 & 2012Q4 & 2013Q1 & 2013Q2 & 2013Q3 & 2013Q4 & 2014Q1 & 2014Q2 & 2014Q3 & $\begin{array}{l}\text { Total } \\
\text { Scores }\end{array}$ \\
\hline Akfen & 0.570 & 0.473 & 0.614 & 0.552 & 0.536 & 0.493 & 0.522 & 0.587 & 0.686 & 0.578 & 0.640 & 0.662 & 0.757 & 0.732 & 0.799 & 9.200 \\
\hline Akmerkez & 0.569 & 0.429 & 0.622 & 0.566 & 0.550 & 0.526 & 0.543 & 0.603 & 0.794 & 0.625 & 0.676 & 0.697 & 0.789 & 0.792 & 0.841 & 9.623 \\
\hline Alarko & 0.563 & 0.412 & 0.603 & 0.543 & 0.505 & 0.392 & 0.478 & 0.572 & 0.649 & 0.549 & 0.606 & 0.519 & 0.689 & 0.444 & 0.707 & 8.232 \\
\hline Atakule & 0.559 & 0.378 & 0.577 & 0.524 & 0.499 & 0.456 & 0.456 & 0.558 & 0.652 & 0.560 & 0.598 & 0.582 & 0.634 & 0.700 & 0.714 & 8.446 \\
\hline Avrasya & 0.632 & 0.502 & 0.633 & 0.594 & 0.653 & 0.577 & 0.757 & 0.880 & 0.896 & 0.830 & 0.758 & 0.751 & 0.764 & 0.748 & 0.806 & 10.781 \\
\hline Deniz & 0.160 & 0.384 & 0.185 & 0.213 & 0.233 & 0.354 & 0.239 & 0.212 & 0.726 & 0.234 & 0.286 & 0.707 & 0.758 & 0.830 & 0.852 & 6.375 \\
\hline Doğuş & 0.564 & 0.422 & 0.607 & 0.544 & 0.530 & 0.464 & 0.507 & 0.579 & 0.661 & 0.561 & 0.634 & 0.665 & 0.768 & 0.739 & 0.802 & 9.045 \\
\hline Halk & 0.548 & 0.433 & 0.612 & 0.552 & 0.535 & 0.424 & 0.524 & 0.595 & 0.682 & 0.581 & 0.644 & 0.666 & 0.759 & 0.733 & 0.798 & 9.085 \\
\hline İdealist & 0.524 & 0.304 & 0.551 & 0.488 & 0.501 & 0.437 & 0.452 & 0.562 & 0.614 & 0.555 & 0.614 & 0.375 & 0.343 & 0.526 & 0.575 & 7.421 \\
\hline İş & 0.569 & 0.435 & 0.614 & 0.555 & 0.541 & 0.498 & 0.527 & 0.594 & 0.701 & 0.590 & 0.674 & 0.702 & 0.775 & 0.743 & 0.817 & 9.335 \\
\hline Kiler & 0.579 & 0.449 & 0.629 & 0.573 & 0.539 & 0.492 & 0.528 & 0.597 & 0.720 & 0.594 & 0.654 & 0.671 & 0.768 & 0.743 & 0.808 & 9.344 \\
\hline Nurol & 0.558 & 0.431 & 0.619 & 0.551 & 0.521 & 0.466 & 0.498 & 0.559 & 0.632 & 0.546 & 0.573 & 0.548 & 0.614 & 0.592 & 0.647 & 8.356 \\
\hline Özderici & 0.557 & 0.263 & 0.605 & 0.542 & 0.479 & 0.485 & 0.515 & 0.582 & 0.673 & 0.577 & 0.638 & 0.669 & 0.753 & 0.730 & 0.799 & 8.867 \\
\hline Pera & 0.566 & 0.437 & 0.612 & 0.551 & 0.536 & 0.529 & 0.500 & 0.586 & 0.676 & 0.593 & 0.657 & 0.684 & 0.754 & 0.727 & 0.793 & 9.201 \\
\hline Reysaş & 0.567 & 0.436 & 0.613 & 0.555 & 0.540 & 0.497 & 0.548 & 0.596 & 0.701 & 0.587 & 0.653 & 0.682 & 0.770 & 0.743 & 0.807 & 9.295 \\
\hline Saf & 0.570 & 0.431 & 0.593 & 0.581 & 0.534 & 0.492 & 0.520 & 0.577 & 0.664 & 0.568 & 0.627 & 0.638 & 0.847 & 0.780 & 0.803 & 9.224 \\
\hline Sinpaş & 0.564 & 0.434 & 0.621 & 0.564 & 0.546 & 0.508 & 0.537 & 0.601 & 0.712 & 0.603 & 0.658 & 0.685 & 0.783 & 0.749 & 0.825 & 9.390 \\
\hline Torunlar & 0.569 & 0.433 & 0.617 & 0.555 & 0.538 & 0.496 & 0.526 & 0.591 & 0.693 & 0.584 & 0.644 & 0.667 & 0.794 & 0.772 & 0.817 & 9.295 \\
\hline TSKB & 0.572 & 0.438 & 0.620 & 0.559 & 0.544 & 0.502 & 0.530 & 0.594 & 0.698 & 0.594 & 0.722 & 0.669 & 0.773 & 0.748 & 0.773 & 9.334 \\
\hline Vakıf & 0.565 & 0.432 & 0.615 & 0.513 & 0.519 & 0.467 & 0.494 & 0.566 & 0.637 & 0.567 & 0.622 & 0.575 & 0.651 & 0.403 & 0.370 & 7.995 \\
\hline Yapı Kredi & 0.563 & 0.426 & 0.611 & 0.549 & 0.539 & 0.491 & 0.524 & 0.593 & 0.737 & 0.606 & 0.659 & 0.691 & 0.866 & 0.723 & 0.805 & 9.384 \\
\hline Yeşil & 0.564 & 0.382 & 0.612 & 0.570 & 0.513 & 0.451 & 0.495 & 0.579 & 0.640 & 0.559 & 0.666 & 0.724 & 0.744 & 0.720 & 0.786 & 9.006 \\
\hline
\end{tabular}




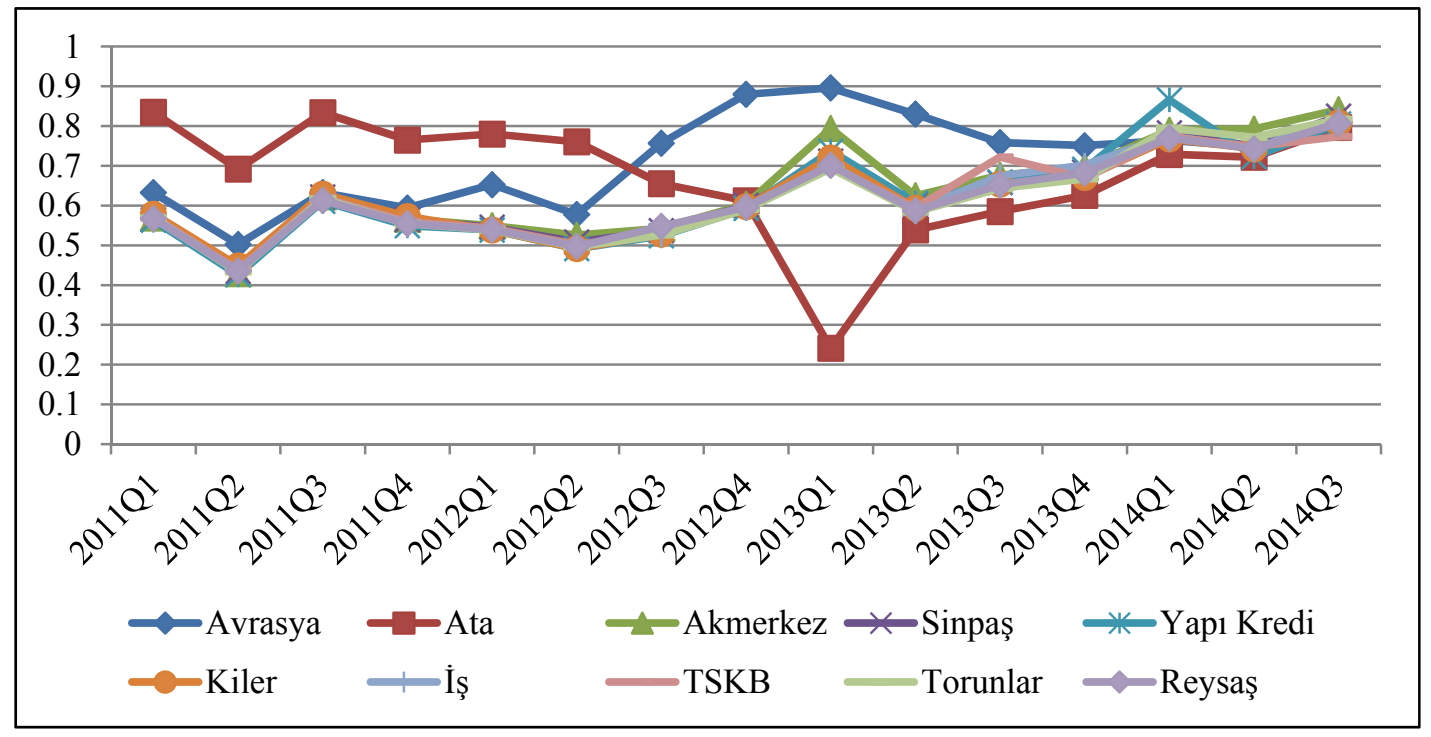

Figure 4. The top ten companies ranked by TOPSIS

In the performance analysis based on TOPSIS scores, in the total of all the period points it can be seen in Figure 4 that the Avrasya Company occupies the first place. Even if the names of the top 10 most successful companies based on the scores and on the rankings are the same, there is a difference in the ranking. The fundamental reason for this difference is that particularly during the periods following 2013Q2, the TOPSIS scores of the companies are very close to each other, from which it can be deducted that the financial performance success of the companies took shape at very close levels during the periods following 2013Q2.

\section{Conclusion}

In this study it was attempted to determine the financial performance of REITs, the securities of which are publicly traded on Borsa Istanbul with the same available kind of data within the period. As companies devising projects based on real estate have a propellant power in the economy, many sectors act jointly with this sector and therefore contribute to a boom in economic activities, which also supports national development. Therefore, the financial performance of the REITs operating in the real estate sector is measured using the Entropy Based TOPSIS Technique.

In this study, the financial performance of REITs was measured by means of liquidity, profitability, turnover and capital structure ratios. The results of the Entropy Method showed that the weighting of liquidity ratios (LK01,LK02,LK03) was found to be high as İdealist, Vakif, Alarko and Atakule had by far the highest liquidity ratios among the REITs. Due to the structure of the industry, as real estate projects are liquidated following their completion, the current assets of the firms notably increase.

Among the REITs, the asset and capital structure ratios (VSY1,VSY2,VSY3,VSY4,VSY5) had closer distance values compared to profitability $(\mathrm{K} 01, \mathrm{~K} 02)$ and turnover $(\mathrm{F} 01, \mathrm{~F} 02, \mathrm{~F} 03)$ ratios, especially the values of capital to asset ratio had the closest distance values. Therefore, the weighting of asset and capital structure criteria were found to be the lowest according to the results of the Entropy Method.

The applicability of the TOPSIS method with the use of the entropy weightings to the problem of REIT financial performance evaluation suggests that it is feasible for different sectors. As the scope of this research was across Turkey, the large number of financial ratios and period intervals and the wideness of the data set can be considered as a valuable resource for further research.

\section{References}

Akkoç, S., \& Vatansever, K. (2013). Fuzzy Performance Evaluation with AHP and Topsis Methods: Evidence from Turkish Banking Sector after the Global Financial Crisis. Eurasian Journal of Business and Economics, 6(11), 53-74.

Bulgurcu, B. (2012). Application of TOPSIS Technique For Financial Performance Evaluation of Technology Firms in Istabul Stock Exchange Market. Procedia Social and Behavioral Sciences, 62, 1033-1040. http://dx.doi.org/10.1016/j.sbspro.2012.09.176 
Chamodrakas, I., Leftheriotis, I., \& Martakos, D. (2011). In-depth analysis and simulation study of an innovative fuzzy approach for ranking alternatives in multiple attribute decision making problems based on TOPSIS. Applied Soft Computing, 11, 900-907. http://dx.doi.org/10.1016/j.asoc.2010.01.010

Çalışkan, H. (2013). Selection of boron based tribological hard coatings using multi-criteria decision making methods. Materials \& Design, 50, 742-749. http://dx.doi.org/10.1016/j.matdes.2013.03.059

Deng, H., Yeh, C. H., \& Willis, R. J. (2000). Inter-company comparison using modified TOPSIS with objective

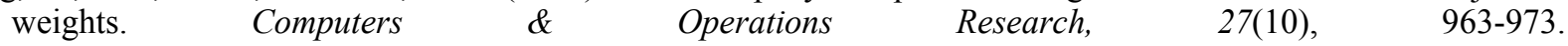
http://dx.doi.org/10.1016/S0305-0548(99)00069-6

Diakoulaki, D., Mavrotas, G., \& Papayannakis, L. (1995). Determinig objective weights in multiple criteria problems: the critic method. Computers \& Operations Research, 22, 763-770.

Ertuğrul, I., \& Karakasoğlu, N. (2009). Performance evaluation of Turkish cement firms with fuzzy analytic hierarchy process and TOPSIS methods. Expert Systems with Applications, 36(1), 702-715. http://dx.doi.org/10.1016/j.eswa.2007.10.014

Hwang C.L., \& Yoon, K. (1981). Multiple Attribute Decision Making: Methods and Applications. Springer, Heidelberg, Berlin.

Hwang, C.L., Lai, Y.J., \& Liu, T.Y. (1993). A new approach for multiple objective decision making. Computers and Operational Research, 20, 889-899. http://dx.doi.org/10.1016/0305-0548(93)90109-V

Julong, D. (1989). Introduction to grey system theory. The Journal of Grey System, 1, 1-24.

Kazan H., \& Ozdemir O. (2014). Financial Performance Assessment of Large Scale Conglomerates via TOPSIS and Critic Methods. Journal of Management and Sustainability, 3(4), 203-224.

Kiyılar, M., \& Hepşen, A. (2010). Performance Appraisal of Real Estate Investment Trusts (REITs): A Practice In Istanbul Stock Exchange. Yönetim Journal, 21(65), 11-23.

Mandic, K., Delibasic B., Knezevic S., \& Benkovic, S. (2014). Analysis of the financial parameters of Serbian banks through the application of the fuzzy AHP and TOPSIS methods. Economic Modelling, 43, 30-37. http://dx.doi.org/10.1016/j.econmod.2014.07.036

Nijkamp, P. (1977). Stochastic quantitative and qualitative multicriteria analysis for environmental design. Papers in Regional Science, 39(1), 175-199.

Önder, E., Taş, N., \& Hepşen, A. (2014). REITs in Turkey: Fundamentals vs. Market. Int. Journal of Latest Trends Finance and Economic Sciences, 4(1), 662-676.

Retrieved 18 March 2015, from http://www.cmb.gov.tr/indexpage.aspx?pageid=5

$\begin{array}{lllll}\text { Retrieved } & 18 & \text { March } & \text { 2015, from }\end{array}$ http://www.etftrends.com/2014/10/europe-reits-etf-for-a-recovering-property-market/

Retrieved 18 March 2015, from www.kap.gov.tr

Retrieved 18 March 2015, from http://www.reit.com/investing/industry-data-research/industry-data

Retrieved 18 March 2015, from http://www.sec.gov/answers/reits.htm

Seçme, N.Y., Bayrakdaroğlu, A., \& Kahraman, C. (2009). Fuzzy performance evaluation in Turkish Banking Sector using Analytic Hierarchy Process and TOPSIS. Expert Systems with Applications, 36, 11699-11709. http://dx.doi.org/10.1016/j.eswa.2009.03.013

Shannon, Claude E., \& Warren, W. (1949). The Mathematical Theory of Communication; Univ. of Illinois. Urbana, 114.

Vincent, L. (1999). The information content of funds from operations (FFO) for real estate investment trusts (REITs). Journal of Accounting and Economics, (26), 69-104.

Wang, Y.J. (2014). The evaluation of financial performance for Taiwan containershipping companies by fuzzy TOPSIS. Applied Soft Computing, 22, 28-35. http://dx.doi.org/10.1016/j.asoc.2014.03.021

Yayar, R., \& Baykara H.V. (2012). TOPSIS Yöntemi ile Katılım Bankalarının Etkinliği ve Verimliliği Üzerine Bir Uygulama. Business and Economics Research Journal, 3(4), 21-42.

Yoon, K. (1980). Systems Selection by Multiple Attribute Decision Making. Ph.D. Dissertation. Kansas State University, Manhattan, Kansas.

Yoon, K. (1987). A reconciliation among discrete compromise situations. Journal of Operational Research Society, $38,277-286$.

Yurdakul, M., \& İç, Y.T. (2003). An Illustrative Study Aimed to Measure and Rank Performance of Turkish Automotive Companies Using TOPSIS. .J. Fac. Eng. Arch. Gazi Univ., 18(1), 1-18.

Zeleny, Milan. (1974). Linear multiobjective programming. Berlin: Springer-Verlag. 